\title{
Impacts of Hurricanes on Fruit Tree Crops in the Caribbean with Emphasis on Hurricane Tomas on Breadfruit (Artocarpus altilis) and Breadnut (Artocarpus camansi) in St Lucia and St Vincent and the Grenadines
}

\author{
Oral 0 Dalley*, Laura B Roberts-Nkrumah, Michael C Gloster and George Legall \\ Department of Food Production, The University of the West Indies, St Augustine Campus, Trinidad and Tobago
}

Submission: July 27, 2020; Published: August 13, 2020

*Corresponding author: Oral O Daley, Department of Food Production, Faculty of Food and Agriculture, The University of the West Indies, St Augustine Campus, Trinidad and Tobago

Abstract

Agriculture, the most important productive sector for many Caribbean countries, is also the most susceptible to climate disasters such as hurricanes, which are expected to increase in frequency and intensity due to climate change. Based on assessments in the crop sub-sector, certain crops have been recognised as being highly prone to negative impacts of hurricanes while others are relatively little affected. There is a dearth of post-hurricane assessment information for fruit tree crops that make substantial contributions to food and nutrition security in the region, both directly and indirectly. This paper reviews the effects of hurricanes in the Caribbean on fruit tree crops and the implications for food and nutrition security and also livelihoods. A case study on the impact of Hurricane Tomas on damage on fruit tree crops with emphasis on breadfruit and breadnut in St Lucia and St Vincent and the Grenadines and lessons on the potential of climate change adaptation and mitigation strategies for the fruit tree crop subsector are presented.

Keywords: Wind damage and loss; Avocado; Breadfruit; Breadnut; Citrus; Coconut; Mango; Nutmeg

\section{Introduction}

The Caribbean has been identified as a region that is highly likely to be negatively impacted by climate change by $2050[1,2]$. Small geographic size, particularly of the islands, stage of development, general over-reliance on economic sectors such as tourism or agriculture, high dependence on food imports and limited development of hazard mitigation measures, all contribute to the high vulnerability of these small states and dependencies. Increased water stress, due either to drought or flooding, and extreme weather events are projected to be major consequences of climate change, with serious consequences for agriculture, and by extension food and nutrition security.

Hurricanes and tropical storms with wind speeds from 115 to over $250 \mathrm{~km} / \mathrm{h}$ are the most frequently occurring natural disasters in the Caribbean [1]. Assessments of the economic and social impacts of 24 disasters in the region from 1972 to 2010, showed that $21(88 \%)$ were related to extreme weather events caused by these high velocity winds [3], which is not unexpected because the region lies in the hurricane belt. Hurricane activities vary greatly throughout the region in frequency and intensity, with the islands north of $10^{\circ} \mathrm{N}$ latitude being at a much higher risk and experiencing more storms than those to the south $[4,5]$. Impact assessments between 1990 and 2008 indicated that within the economic sector, $23.82 \%$ of the damage and $21.6 \%$ of the losses were in the agriculture and forestry subsector [1]. However, over the longer period of 1972 to $2010,53 \%$ of the damage estimated within the production sector occurred in agriculture and forestry and, in comparison to the social and infrastructural sectors, production incurred $83.2 \%$ of the losses, mostly within agriculture and forestry [3]. The impact of hurricanes and storms on crop production and on the supply of crops for domestic consumption is not clear from the reports of most of the assessments because the data were not disaggregated. Available information usually relates to export crops. For example, in 2004 crop losses in Grenada due to Hurricane Ivan were $100 \%, 90 \%$ and $40 \%$ for banana (Musa spp.), nutmeg (Myristica fragrans) and cocoa (Theobroma cacao), respectively, while in St Lucia, $67 \%$ of the banana crop was lost to Hurricane Dean in 2007 (FAO 2015) [6]. Lack of clear information 
on the impacts of high velocity winds on individual crops, negatively affects the planning and modelling of strategies for climate change adaptation for those crops in the Caribbean.

Although it is not widely documented, indigenous and introduced tree crop species, for example, avocado (Persea americana), guava (Psidium guajava), ackee (Blighia sapida), mango (Mangifera indica), breadfruit (Artocarpus altilis) and tamarind (Tamarindus indica), have been traditionally important to food and nutrition security in the Caribbean at different seasons of the year [7-9]. Additionally, crops such as coconut (Cocos nucifera), mango, breadfruit, avocado and golden apples (Spondias dulcis) have proven to be of direct economic value on the local and export markets through their significant contributions to the agricultural diversification programmes implemented in some countries [1012]. Being perennials, tree crops are of particular interest for the indirect economic benefits they provide through ecosystem services that reduce degradation in soil and water quality, as well as other environmental changes that result in declining productivity of shorter-term crops. However, while substantial literature on the impact of hurricanes on Caribbean forests is available, studies on the effect of wind stress on fruit tree crops in the region are very limited.

Assessment of the impacts of Hurricane Gilbert, which directly hit Jamaica in 1988 with average wind speed of $200 \mathrm{~km} / \mathrm{h}$, showed that $91 \%$ of 1859 trees at the University of the West Indies, Mona Campus, was damaged or destroyed [13]. Fruit trees, among which ackee and mango appeared to be the most numerous, suffered light to severe damage, including toppling [13]. Similar assessments of 2995 and 2451 trees at that location in 2004 and 2007, respectively, showed that $55 \%$ and $33 \%$ of the trees were lightly to severely damaged or completely lost after Hurricanes Ivan and Dean, which had average wind speeds of $64 \mathrm{~km} / \mathrm{h}$ and $80 \mathrm{~km} / \mathrm{h}$, respectively [14]. Crane, Campbell \& Balerdi [15] reported that fruit tree species in Florida, suffered various levels of damage from Hurricane Andrew. The highest incidence of tree loss occurred in mango, longan (Dimocarpus longan) and lychee (Litchi chinensis), the highest level of toppling (77\%) occurred in atemoya (Annona x atemoya) and the highest level of stumping (44\%) occurred in mamey sapote (Pouteria sapota) [15]. Similar information on the level of damage and loss caused by hurricanes to fruit tree species in the Caribbean is not available or limited.

Hurricane Tomas was the $19^{\text {th }}$ named storm and $12^{\text {th }}$ hurricane of the 2010 Atlantic hurricane season, which affected several islands of the Caribbean from October 29 to early November with maximum winds of $157.4 \mathrm{~km} / \mathrm{h}(97.8 \mathrm{mph})$, and maximum rainfall of $66 \mathrm{~cm}$ (26.3") over a 23 hour period [16]. The hurricane passed south of St Lucia and north of St Vincent on October 30, resulting in loss of lives and significant damage to homes and crops, including fruit tree crops $[17,18]$. A study was conducted to provide information on the nature of tree damage caused by Hurricane Tomas and some factors associated with vulnerability to hurricane damage among fruit tree crops in the Eastern Caribbean, with special reference to breadfruit and breadnut.

\section{Materials and Methods}

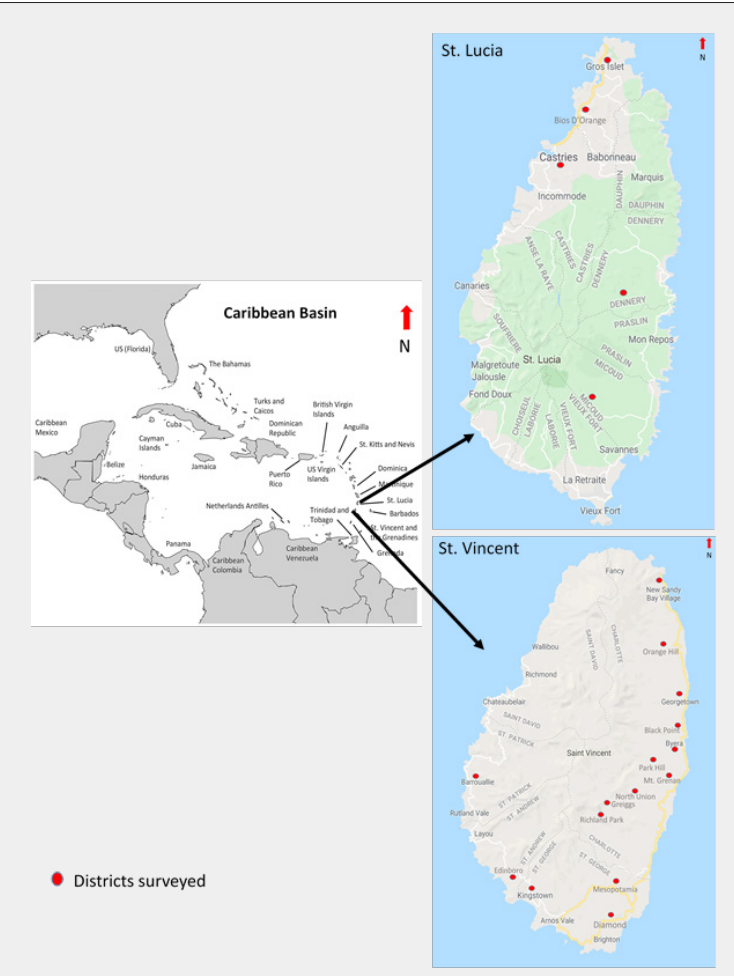

Figure 1: Maps of St. Lucia and St. Vincent with districts involved in the survey. 
From November 11 to 16, 2010 a survey was conducted in St. Lucia and St. Vincent following the passage of Hurricane Tomas. Several districts across both islands were surveyed (Figure 1). Questionnaires were administered face to face to 48 respondents who were selected based on willingness to participate in the survey and in locations which were accessible by roads at the time of the survey. The respondents were classified as farmers who owned or managed fruit trees on their farms or at home, as well as home gardeners who owned or managed fruit trees in their home gardens. All respondents were required to have at least one breadfruit or breadnut tree growing on the property they owned or managed.

Respondents were asked to identify the species of fruit trees growing on their property, to describe the types of damage caused by Hurricane Tomas as well as, management of the trees prior to the hurricane and to indicate the purpose for which they grew breadfruit and breadnut. Direct observations were also made on trees owned or managed by respondents. These observations included the level of damage to the foliage, main branches and trunk, and tree anchorage. The topography and level of exposure for each site were also recorded.

Descriptive and inferential statistical data analyses were carried out using IBM SPSS Version 21 [19]. Descriptive statistical methods included frequencies, percentages, and means. Inferential methods included Chi-square test of association and analysis of variance (ANOVA).

\section{Results}

\section{Demographics}

Among the 48 respondents who participated in the survey, those in St. Vincent accounted for $81.25 \%$ while those in St. Lucia accounted for $18.75 \%$ (Table 1). Most respondents (58.3\%) were males, and $41.7 \%$ was females. Respondents between the ages of $46-60$ years comprised $41.7 \%$ followed by respondents over the age of $60(31.3 \%)$, while those between 18 and 35 years old comprised only $8.3 \%$. No respondent from St. Lucia was in the age range of $18-35$. Twenty- nine respondents $(60 \%)$ were farmers while 19 (40\%) were home gardeners.

Table 1: Demographics of respondents in St. Lucia and St. Vincent $(n=48)$.

\begin{tabular}{|c|c|c|c|c|}
\hline \multicolumn{2}{|c|}{$\begin{array}{c}\text { Cespondents } \\
\text { St. Lucia }\end{array}$} & \multicolumn{2}{c|}{ Countries } & \multirow{2}{*}{ Total (\%) } \\
\cline { 2 - 5 } Sex & Male & 5 & 23 & $28(58)^{*}$ \\
\cline { 2 - 5 } & Female & 4 & 16 & $20(42)$ \\
\hline \multirow{3}{*}{ Age Range } & $18-35$ & 0 & 4 & $4(8)$ \\
\cline { 2 - 5 } & $36-45$ & 4 & 5 & $9(18.8)$ \\
\cline { 2 - 5 } & $46-60$ & 3 & 17 & $20(41.7)$ \\
\hline \multirow{3}{*}{ Status of Producers } & $>60$ & 2 & 13 & $15(37.5)$ \\
\cline { 2 - 5 } & Farmers & 7 & 22 & $29(60.4)$ \\
\hline Country Total (\%) & & 2 & 17 & $19(39.5)$ \\
\hline
\end{tabular}

*Values in parentheses give the percentage of total respondents for each category.

\section{Site characteristics}

Site characteristics were recorded in terms of slope and level of exposure. Over all sites in the survey, $42.6 \%$ was moderately sloped, $40.4 \%$ was flat and $17 \%$ was steeply sloped. There was no significant association $\left(\chi^{2}=4.957, \mathrm{df}=2, \mathrm{p}=0.084\right)$ in the distribution of slopes between the two countries. However, St. Vincent tended to be more sloping with $50 \%$ of sites being moderately sloped, $36.8 \%$ was flat and $13.2 \%$ was considered steeply sloped. For St. Lucia, $55.6 \%$ of the sites was flat, $33.3 \%$ was steeply sloped and $11.1 \%$ was moderately sloped.

In terms of site exposure, $80.9 \%$ of all sites in the survey was classified as exposed and $19.1 \%$ as sheltered. There was no significant association $\left(\chi^{2}=2.636, \mathrm{df}=2, \mathrm{p}=0.104\right)$ in the distribution of site exposure between the two countries. All sites in St. Lucia were classified as exposed while $76.3 \%$ of sites in St. Vincent was considered as exposed.

\section{Tree species}

Data were collected in 2070 damaged trees from the 48 sites across the islands of St. Lucia and St. Vincent. Eight fruit tree species: breadfruit, breadnut, cocoa, avocado, mango, citrus, nutmeg and coconut were reported by respondents. Cocoa was the most abundant species in the survey with 1760 trees followed by breadfruit with 222 .

\section{Types of damage}

Six types of damage were observed in the survey and at least four types of damage affected all tree crops. There was significant $(p \leq 0.05)$ difference among the fruit tree species in terms of the 
types of damage they sustained. Defoliation, fruit loss and slight branch breakage was the most common type of damage for all species except cocoa and nutmeg (Figure 2). Moderate branch breakage and severe branch breakage were the next most frequent types of damage among most species, and severe branch breakage was highest in cocoa. Partial uprooting was observed among all species and ranged from $6.7 \%$ in mango to $20 \%$ in nutmeg. Breadfruit and breadnut experienced $12.6 \%$ and $10.5 \%$, partial uprooting, respectively. Nutmeg (30.6\%) and breadfruit (17.6\%) appeared to be the two most vulnerable species to complete uprooting. No mango tree was affected by complete uprooting suggesting that it was the least vulnerable to this type of damage, followed by breadnut (5.3\%), avocado (7.1\%) and coconut (9.1\%).

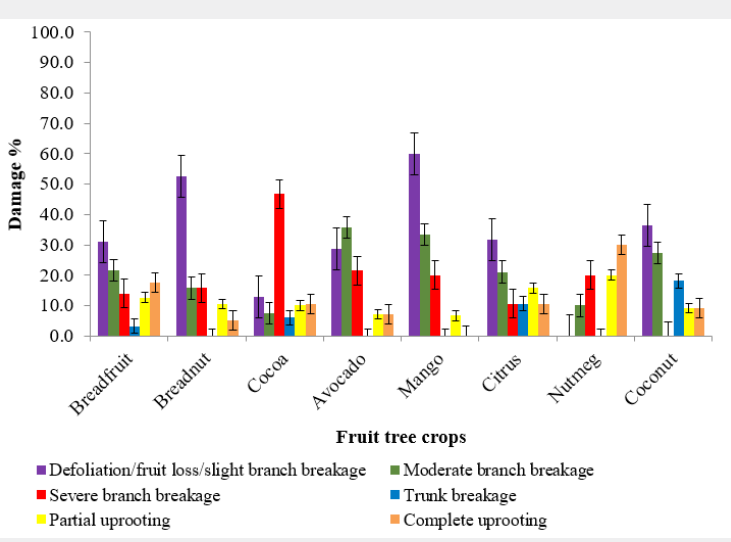

Figure 2: Types of damage sustained by fruit tree crops.

\section{Purpose for breadfruit and breadnut production}

All respondents had breadfruit or breadnut growing on their property and $59 \%$ of respondents reported that trees were in bearing at the time of the hurricane. The bearing of fruit at the time of the hurricane was recorded in both countries. Approximately $75 \%$ of respondents grew breadfruit or breadnut for both home consumption and sale, while $20.8 \%$ produced these crops only for home consumption. Few farmers and home gardeners $(4.2 \%)$ grew breadfruit or breadnut for sale only. There was no significant association $\left(\chi^{2}=1.25, \mathrm{df}=2, \mathrm{p}=0.536\right)$ between purpose of breadfruit or breadnut production and countries. There was also no significant association $\left(\chi^{2}=5.168, \mathrm{df}=2, \mathrm{p}=0.075\right)$ between purpose of production and status of producers since most of the respondents across both categories were involved in breadfruit and breadnut production for home use and sale. The majority of farmers (86\%) produced breadfruit or breadnut for home use and sale while $10 \%$ was involved in production for home use and gifts only. Among home gardeners, 58\% produced breadfruit or breadnut for home use and sale while 37\% produced these crops for home use and gifts only.

\section{Breadfruit and breadnut production systems and tree man- agement}

No pure stand production system was reported for breadfruit or breadnut in this survey. Backyard production, which was recorded for $31 \%$ of the respondents, was the dominant production system followed by border crop (28\%) and mixed cropping with other tree crops (15\%).There was a significant association between status of producers and type of cropping systems $\left(\chi^{2}=\right.$
12.911, $\mathrm{df}=4, \mathrm{p}=0.012$ ). Backyard production of breadfruit and breadnut was more prevalent among home gardeners than among farmers. Single tree production was reported only among homeowners while border crop was reported only among farmers. Mixed production systems, whether with short term crops or other tree crops, were more prevalent among farmers. There was no significant association between purpose of breadfruit or breadnut production and production systems $\left(\chi^{2}=6.103, \mathrm{df}=8, \mathrm{p}=0.636\right)$. Fruit bearing at the time of the hurricane was reported for all production systems and there was no significant association between bearing and production systems $\left(\chi^{2}=0.959, \mathrm{df}=4, \mathrm{p}=0.916\right)$.

Only $11.9 \%$ of respondents did any form of pruning within the last year before the hurricane. Furthermore, there was no significant association between pruning practices and countries $\left(\chi^{2}=\right.$ $0.959, \mathrm{df}=1, \mathrm{p}=0.673)$, production systems $\left(\chi^{2}=4.032, \mathrm{df}=4, \mathrm{p}=\right.$ $0.402)$, status of producer $\left(\chi^{2}=0.890, \mathrm{df}=1\right)$ and types of damage to tree $\left(\chi^{2}=5.876, \mathrm{df}=6, \mathrm{p}=0.437\right)$.

\section{Discussion}

The present study showed that several fruit tree crops were grown on farms and home gardens in St. Lucia and St. Vincent. Fruit tree crop production, whether on farms or home gardens, have been a long-standing tradition of the Caribbean. Farmers and home gardeners depend on these crops to provide food and income. With the emphasis given to breadfruit and breadnut in this study, it was clear that these crops were important in both islands based on the combined number of respondents who either produced them for home use and gift or for home use and sale. These results were similar to findings of Gloster \& Roberts-Nkru- 
mah [20] who reported that among home gardeners in St. Vincent, breadfruit was well appreciated and consumed in all households in the study. Another study in Trinidad also showed that most farmers produced breadfruit and breadnut for home consumption [9]. The fact that breadfruit and breadnut were also sold by respondents, suggests that these crops make a valuable contribution to family incomes. Since a majority of respondents reported that trees were in bearing at the time of the hurricane, fruit losses were likely to be significant. These losses may have major economic impact on farmers and home gardeners who depend on the sale of the fruit for income. This was also likely to be true for other crops mentioned in the study. The results of this study, along with previous studies, show that breadfruit, breadnut and other fruit tree crops have the potential to contribute more to food and nutrition security and livelihoods among the wider populations of these islands.

The production of fruit trees is considered a capital investment because of the considerable time and resources that must be invested before any returns can be realized. When damage is done, it may take years for famers and the wider industry to recover because of the long growing cycles of these perennial species. Therefore, the issue of vulnerability to hurricane and other natural disasters in the fruit tree crop subsector is unique compared to other agricultural crops that have shorter growing cycles. Furthermore, with expected increases in hurricane activity in Caribbean due to climate change, special attention must be given to developing adaptation and recovery strategies to help reduce the impact of hurricanes and other natural disasters. These strategies must be done within the context of the potential damage and losses.

Physical damage to tree species associated with hurricanes has been reported but there have been few comparisons among different fruit tree crop species in the Caribbean. The result of this study showed that fruit tree crop species were susceptible to several types of damage caused by hurricanes, including defoliation, branch breakage, trunk breakage and uprooting. Defoliation and fruit loss were the most common types of damage, followed by branch breakage. This was similar to results reported for forest tree species in the Caribbean [21] and fruit tree species in Florida [22]. However, fruit tree species also differed in their susceptibility to hurricane damage. In the present study, breadfruit and nutmeg experienced more severe damage compared to breadnut, mango and orange. Jamaica montane forest species were also affected differently by Hurricane Gilbert in 1988 which allowed for the identification of four-damage categories, namely, resistant with low damage and low response; susceptible with high damage and low response; resilient with high damage and high response and usurpers with low damage and high responsiveness [23].

Architectural features of trees such as crown to stem ratio, tree height, canopy density, branch distribution and root system, influence tree susceptibility to damage. Bellingham, Tanner
\& Healey [23] suggested that the greater crown to stem ratio of Pittosporum undulatum compared to other species may have contributed to the high level of uprooting observed in the montane forest of Jamaica after Hurricane Gilbert. Crane et al. [22] reported that species with greater rooting depth and orchard management practices that encourage greater rooting depth helped trees to withstand hurricane force winds better. Breadnut is usually propagated from seeds; therefore, mature trees have a taproot system, compared with breadfruit trees that are propagated through vegetative means resulting in mature trees having large buttress roots but no taproots. Other studies also indicated that tree species with a taproot system are less prone to uprooting in a hurricane than those that lacked taproots. Tahiti lime (Citrus $\times$ latifolia) trees which were propagated by grafting on seedling rootstocks showed greater ability to survive hurricanes compared to those which were propagated by air-layering [15]. Based on the relative difference observed in the level of uprooting between breadnut and breadfruit in this study, grafted breadfruit using breadnut rootstock, which is currently being evaluated, may reduce the level of uprooting of breadfruit trees which may improve the ability of breadfruit trees to survive hurricanes [24,25] .

Tree height also plays a major role in tree susceptibility to damage by hurricanes. Crane et al. [22] reported that orchards in which tree height was maintained at 3.7 to $6.7 \mathrm{~m}$ had more upright trees after a hurricane compared to orchards in which tree height control was not practised. The result of the current study showed that only $11.9 \%$ of respondents had done any form of pruning up to one year before Hurricane Tomas. Furthermore, the lack of association between status of producers and pruning indicated that pruning was not a common practice for any group. This is not unusual, as breadfruit and breadnut and some of the other crops reported in this study are not traditionally pruned in the Caribbean. Additionally, our results showed that the most common type of production system used to produce the crops in the survey was backyard planting. This production system is often associated with minimum management of tree crops. Tree height control, including pruning, was reported as the most beneficial pre-hurricane cultural practice to reduce tree damage and toppling [22]. Neglect of tree height management among producers in this study may be associated with lack of knowledge of the benefits of pruning and proper pruning practices.

The characteristics of the production area or site may also contribute to the susceptibility of tree crops to hurricane damage. Site characteristics in the current study focussed on topography and level of exposure. Most of the sites studied in the survey were moderately or steeply sloped and exposed. These factors likely contributed to the high level of damage reported in this study. However, previous studies indicated that while slopes contribute to susceptibility to damage, the direction of the slope is probably more important. A comparison of the direction of slope was not done in this study but the data were collected in windward locations that were most affected by Hurricane Tomas. Other studies 
have shown that forests on slope facing windward, experienced more damage than forests on leeward slopes [26,27]. These results showed that site selection is important for the establishment of fruit tree species in the Caribbean to help minimize damage caused by hurricanes. Where it is not feasible to avoid exposed sites for orchard establishment, it is recommended that windbreaks be used to help minimize the effects of hurricane damage [22].

\section{Conclusion}

Fruit tree crops are important for livelihood and food and nutrition security in St. Lucia and St. Vincent, and the Grenadines. Because of their long growing cycles, the time for recovery from natural disasters can be considerable compared to other crops with shorter growing cycles. Therefore, adaptation and recovery strategies must meet the specific requirements for these crops and even individual species. The various species sustained different types and degree of damage. Besides species characteristics, other factors such as tree height, root system, cultural practices and site characteristics appears to influence susceptibility to damage. Some of these factors can be mitigated by proper planning in terms of site selection, choice of planting materials, and the use of cultural practices such as pruning for tree height management.

\section{Acknowledgement}

The authors gratefully acknowledge the assistance and support of the following: the Economic Commission for Latin America and the Caribbean (ECLAC) and the Ministries of Agriculture of St. Lucia and of St. Vincent and the Grenadines for providing ground transportation and logistical support throughout the survey, the Department of Food Production, Faculty of Food and Agriculture of The University of the West Indies for providing financial support. Sincerest gratitude is also extended to all respondents for participating in the survey.

\section{References}

1. Economic Commission for Latin America and the Caribbean (ECLAC) (2010) Analysis of Extreme Events in the Caribbean 1998-2008.

2. Hutchinson S, Gomes C, Alleyne D, Phillips W (2013) An Assessment of the Economic and Social Impacts of Climate Change on the Agriculture Sector in the Caribbean. Port of Spain, Trinidad and Tobago: ECLAC.

3. Omar B, Ortiz L, Samaniego J (2015) Assessment of the Effects of Disasters in Latin America and the Caribbean, 1972-2010. In Environment and Development. Santiago: Economic Commmission on Latin America and the Caribbean (ECLAC).

4. Erik H, Pantin D, Attzs M, Bruce J, MacKinnon J (2002) Assessment of the Economic Impact of Climate Change on CARICOM Countries. World Bank Technical Paper.

5. Pielke RA, Rubiera J, Landsea C, Fernández ML, Klein R (2003) Hurricane Vulnerability in Latin America and the Caribbean: Normalized Damage and Loss Potentials. Natural Hazards Review 4(3): 101-114.
6. Food and Agriculture Organisation of the United Nations (FAO) (2015) Addressing Disaster Risk Management in Caribbean Agriculture. Barbados, Sub-regional Office for the Caribbean: Food and Agriculture Organisation of the United Nations.

7. John R (2002) Evidence of Seasonal Hunger in the-Oral Traditions of Jamaicans. In: Steeps JR, Wyndham FS, Zarger RK (Eds.), Ethnobiology and Biocultural Diversity Conference Proceedings, Georgia: International Society of Ethnobiology.

8. Roberts-Nkrumah LB (2007) An Overview of Breadfruit (Artocarpus altilis) in the Caribbean. Acta Horticulturae 757: 51-60.

9. Roberts-Nkrumah LB, George L (2013) Breadfruit (Artocarpus altilis, Moraceae) and Chataigne (A. camansi) for Food Security and Income Generation: The Case of Trinidad and Tobago. Economic Botany 67(4): 324-334.

10. Government of Grenada (2011) Annual Review Grenada 2009. St. George Grenada: Ministry of Agriculture, Forestry and Fisheries.

11. Inter-American Institute for Cooperation on Agriculture (IICA) (2009) IICA's Contribution to the Development of Agriculture and Rural Communities St. Lucia. St. Lucia: Inter-American Institute for Cooperation on Agriculture.

12. Christoph R, Leal W (2008) Diversification of the Agro-Economy of St. Lucia - Identification of Cash Crops and Service Plants for Cultivation Systems Adapted to the Economic Needs and Pedoclimatic Conditions - A Desktop Study. Hamburg, Germany: Hamburg University of Applied Sciences.

13. Dave GH, Henry RA (1988) Effect of Hurricane Gilbert on trees at the University of the West Indies Mona Campus. In Report presented to the Gilbert Trees Committee. Kingston, Jamaica: The University of the West Indies, Mona Campus.

14. Dave GH, Cohen JE, Daley DA, Baldy RR (Updated) Damage to Trees at the UWI Mona Campus caused by Hurricanes Gilbert, Ivan \& Dean. Kingston, Jamaica: The University of the West Indies, Mona Campus.

15. Crane JH, Campbell RJ, Balerdi CF (1993) Effect of Hurricane Andrew on Tropical Fruit Trees." In Proceeding- Florida State Horticultural Society 106: 139-144.

16. Pasch RJ, Kimberlain TB (2011) Tropical Cyclone Report Hurricane Tomas. National Hurricane Center.

17. Pan American Health Organization (PAHO) (2019) Hurricane Tomas Hits Islands of the Caribbean.

18. Searchlight (2010) Agriculture Devastated by Passage of Hurricane Tomas.

19. IBM Corporation (2012) IBM SPSS Statistics for Windows, Version 21.0. Armonk, NY: IBM Corporation.

20. Michael G, Roberts-Nkrumah LB (2012) The Importance of Breadfruit Grown in Home Gardens in St. Vincent and the Grenadines. In: Lugo WI, Colón W (Eds.), Proceedings of the Caribbean Food Crop Society 48th Annual Meeting 2012, 48: 115-123. Playa del Carmen, Mexico: Caribbean Food Crop Society.

21. Brokaw NVL, Walker LR (1991) Summary of the Effects of Caribbean Hurricanes on Vegetation. Biotropica 23(4): 442-447.

22. Crane J, Balerdi C, Campbell R, Campbell C, Goldweber S (1994) Managing Fruit Orchards to Minimize Hurricane Damage. Hort Technology 4(1): 21-27.

23. Bellingham PJ, Tanner EVJ, Healey JR (1995) Damage and Responsiveness of Jamaican Montane Tree Species after Disturbance by a Hurricane. Ecology 76(8): 2562-2580. 
24. Medagoda I, Kumari Chandrarathna WMCJ (2007) Grafting of Breadfruit (Artocarpus altilis) Using Breadnut (Artocarpus camansi) as Root Stock. Acta Horticulturae 757: 149-152.

25. Solomon FK, Roberts-Nkrumah LB, Rouse-Miller JA (2012) Development of a Grafting Protocol for the Commercial Propagation of Three West Indian Breadfruit Cultivars. Tropical Agriculture 89(2): 85-98.
26. Bellingham PJ (1991) Landforms Influence Patterns of Hurricane Damage: Evidence from Jamaican Montane Forests. Biotropica 23(4): 427-433.

27. Reilly AE (1991) The Effects of Hurricane Hugo in Three Tropical Forests in the U.S. Virgin Islands. Biotropica 23(4): 414-419.

DOI:10.19080/IJESNR.2020.25.556167

\section{Your next submission with Juniper Publishers} will reach you the below assets

- Quality Editorial service

- Swift Peer Review

- Reprints availability

- E-prints Service

- Manuscript Podcast for convenient understanding

- Global attainment for your research

- Manuscript accessibility in different formats ( Pdf, E-pub, Full Text, Audio)

- Unceasing customer service

Track the below URL for one-step submission https://juniperpublishers.com/online-submission.php 